\title{
Institutional Investors And The Finance- Growth Nexus: Evidence From South Africa
}

\author{
Mabutho Sibanda, University of KwaZulu-Natal, South Africa \\ Merle Holden, University of KwaZulu-Natal, South Africa
}

\begin{abstract}
Since the 1990s assets of institutional investors have remained elevated in comparison to those of deposit-taking financial institutions in South Africa. This paradigm shift in the financial markets has provoked the ongoing theoretical and empirical debate, which, on the one hand, pits institutional investors as causing financial 'disintermediation' against, on the other hand, deposittaking financial institutions in promoting economic development. These and other conflicting views on financial intermediation have promoted the 'finance-growth nexus' hypothesis, which draws lessons from the Patrick (1966) 'demand-following' and 'supply-leading' propositions (Patrick, 1966). The study uses the Johansen (1991) co-integration tests, the vector error correction and the Granger causality approaches to establish the role played by institutional investors in the finance-growth nexus in South Africa based on quarterly data spanning 1994 to 2009. Findings suggest that a 'demand-following' phenomenon exists in South Africa in which the growth in the institutional investors' industry is dependent upon the level of economic development and banking sector development.
\end{abstract}

Keywords: Institutional Investors; GDP per Capita; Disintermediation; Finance-Growth Nexus

\section{INTRODUCTION}

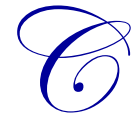

hanges have been observed in the financial intermediation process over the past three decades which have been driven by increased surplus funds in the early 1970s, globalization and technological advances. These factors have led to changes in the financial system, in particular to banking and nonbanking financial institutions. The greatest changes include a relative decline in the proportion of total financial assets held by banks and the failure of several asset bubbles (Bisignano, 1998). Changing financial deregulation is also cited by Bisignano as one of the reasons for the near collapse of banks in the 1990s. Furthermore, the mushrooming of new institutional investors has brought with it price instability in financial markets. Arguments in favour of the current behaviour of institutional investors in modern capital markets have been put forward in recent scholarly work. For instance, Allen and Santomero argue that the current theory of financial intermediation has been too dependent on reducing market frictions of transaction costs and asymmetric information, which have increasingly become irrelevant (Allen \& Santomero, 1997). This twofold role of intermediaries is more functional than institutional and leads to a new paradigm shift from the present (stylized) theory which suggests that there is now financial disintermediation in addition to dynamics of intermediation which emanate from new markets and products (Scholtens \& Van Wensveen, 2000).

The traditional view of financial intermediation is provided by the neoclassic economic theory, which states that financial intermediaries are a means of allocating financial resources from economic units in surplus to those in deficit. These financial resources would then be used for the production of goods and services to support the real economy (Solow, 1956). Patrick (1966) set out two propositions that financial intermediaries are either 'demandfollowing' or 'supply-leading' in the economy. The demand-following proposition means that financial institutions develop in response to economic development. On the other hand, the supply-leading proposition means financial 
intermediaries influence economic development. However, the advent of innovative securities, surplus funds, increased technological advances and the integration of global financial markets have changed the financial system landscape over the past decades. Thus, accompanying the integration of world financial markets has been financial 'disintermediation' that has particularly been observed since the early 1990s. As such, arguments have been put forward pointing to changes in the structure of the financial system, which is led by increasing activity in institutional investor or non-bank financial intermediaries. Non-bank financial institutions refer to institutional investors such as pension funds, insurance companies and collective investment schemes (commonly known as mutual funds). The terms 'non-bank financial intermediaries' and 'institutional investors' are used interchangeably in this paper. The new role of non-bank financial intermediaries may be taken as financial disintermediation due to the competing nature of these intermediaries with deposit taking institutions like banks (Davis, 2001). In the same manner, the South African financial system has also become complex and dynamic with growing stock markets and institutional investors which have remained elevated relative to the banking assets.

In response to these structural changes in the financial system, several studies have sought to establish the role of the financial sector in economic development, and the consensus points to finance leading economic development especially in developed countries (Arestis \& Demetriades, 1997; Dermirguc-Kunt \& Levine, 1999; Dritsakis \& Adamopoulos, 2011). It has also been found that economies that have a well-developed banking sector and stock market tend to grow faster than those to the contrary (Levine, 1997; Levine \& Zervos, 1998; Levine \& Zervos, 1996). However, very few studies have attempted to disintegrate financial development to ascertain the role played by institutional investors in economic and financial development. Financial development consists of banking sector development, stock market development, financial deepness and the development of the non-bank financial sector.

\section{BACKGROUND AND RESEARCH HYPOTHESES}

The South African financial system is well developed and is ranked 28 out of 62 in the Financial Development Index of 2012, with a score of 3.7 out of $1-7$, where 1 represents the best score (World Economic Forum, 2012). The individual segments of financial markets further show that financial development varies considerably within the financial sector. For instance, stock market development ranks 2 out 62 (252 percent of GDP); non-bank financial services 22 out of 62 (score: 2.4); deposit money bank assets to GDP ranked 32 out of 62 (82.3 percent); and banking financial services ranked 38 out of 62 (Score: 3.5) (World Economic Forum, 2012). From these figures, it is evident that the non-bank financial services are more developed than the banking financial services, although literature on the influence of the former on economic development remains low. Non-bank financial institutions are regulated by the Financial Services Board Act of 1990 while banks are regulated by the Banks Act of 1990. Based on the foundations laid by Demirguc-Kunt and Levine (1999), ratios for financial deepness or financial development as represented by bank assets to GDP, stock market capitalization to GDP, and bank assets to non-bank financial institutions assets to GDP ratios show that non-bank financial institutions dominate the South African financial system as shown in Table 1.

Table 1: Bank Assets versus Other Financial Assets

\begin{tabular}{|l|c|c|}
\hline \multicolumn{1}{|c|}{ Ratio } & $\mathbf{1 9 9 4}$ & $\mathbf{2 0 0 9}$ \\
\hline Total assets of banks (\% of GDP) & 71 & 124 \\
\hline Assets of banks/assets of institutional investors' assets (\%) & 57 & 66 \\
\hline Total assets of institutional investors (\% of GDP) & 125 & 186 \\
\hline Stock market capitalization (\% of GDP)* & 166 & 249 \\
\hline
\end{tabular}

Source: SARB Online Statistics. * denotes figures from The World Bank Development Indicators. [Institutional investors' assets figure is derived by aggregating assets of pension funds, provident funds, the Public Investment Corporation, mutual funds, and short-term and long-term insurance companies. The asset values were obtained from SARB Online Statistics]

Of interest is the growing institutional investors' asset to GDP ratio, clearly suggesting the growing importance of institutional investors on financial development in South Africa. This suggests that the South African financial sector growth over the past two decades may have been influenced by institutional investors in addition to the influence of the robust banking sector, financial deepness and stock market as illustrated by the World Economic Forum Indicators above. In this study, financial development is represented by financial deepness (broad money supply to GDP ratio), banking sector development (bank credit to private sector to GDP ratio), and stock market 
development (stock market capitalization to GDP ratio). Institutional investors refer to the summation of assets of long-term insurance companies, short-term insurance companies, mutual funds, the Public Investment Corporation and pension funds and provident funds. Thus, the influence that these investors have on both financial development and economic development needs to be investigated further with a view to determining the direction of causality among them, if any, and whether any long-run co-integrating relationships exist. These established relationships will lead to the inferences being drawn on their influence of the finance-growth nexus in South Africa.

This study, therefore, seeks to establish the influence of non-bank financial institutions on both financial development and economic development in South Africa. To establish this relationship, the study tests three hypotheses which are based on South African quarterly data spanning 1994 to 2009 as follows:

$\mathbf{H}_{1}$ : Institutional investors influence financial development.

$\mathbf{H}_{2}$ : Institutional investors influence economic development.

$\mathbf{H}_{3}$ : Institutional investors influence gross capital formation.

$\mathrm{H}_{1}$ will further categorize financial development into financial deepening, banking sector development and stock market development, while economic development is represented by real per capita GDP.

\section{LITERATURE REVIEW}

The finance-growth nexus has been widely researched worldwide. However, very little has been done to establish the role played by institutional investors in this finance-growth nexus. This is particularly so in South Africa, a country that has a robust financial system (International Monetary Fund (IMF), 2011). The influence of financial development on economic development has been found to be unidirectional, running from the former to the latter (Aziakpono, 2003). Aziakpono postulates that economies should develop their financial sectors in order to realize regional integration benefits and, more importantly, drive economic growth in their countries. Other countryspecific studies have been conducted on the relationship between financial development and economic growth, for instance in Malaysia (Choong, Yusop, Law, \& Sen, 2005; Islam \& Osman, 2007); China (Allen, Qian, \& Qian, 2005; Demetriades \& Luintel, 1997; Liu, Song, \& Romilly, 1997); Singapore (Harichandra \& Thangavelu, 2004); and Jordan (Abu-Muhareb \& Al-Fayoumi, 2011). These studies have shown that financial development leads to economic growth in these respective countries. Islam and Osman (2011) conducted a study on the development impact of non-bank financial intermediaries on economic growth in Malaysia using the bounds testing approach to co-integration and error correction mechanism, and found that non-bank financial institutions had a positive and significant impact on long-run per capita real GDP in Malaysia.

Another key study on the role of institutional investors in the development of the financial sector and economic growth in Organisation for Economic Co-operation and Development (OECD) countries was conducted by Harichandra and Thangavelu (2004). This study incorporated the dynamic causality role of institutional investors in a Panel Vector Autoregressive framework based on a cross-sectional time series variability data of 23 OECD countries from 1988 to 1999. The study focused on five aspects of institutional investors, financial markets and economic growth. The relationship between aggregate institutional investors and financial sector development showed a strong causal impact of institutional investors in OECD countries on the development of the stock markets. Thus it was found that institutional investment Granger causes stock market capitalization; the value of stock traded and turnover ratios and reverse causality was observed from stock market capitalization only. Further, it was found that there was no causality running either from institutional investors to banking sector development or from banking sector development to institutional investors. Further, the study found a unidirectional causality running from institutional investors to GDP without any reverse feedback.

The existence of the non-bank financial intermediaries should be a function of value addition to the financial system above their traditional primary function of reallocation of resources within the economy. These financial intermediaries are larger as a share of GDP in richer countries than in less developed countries (DermirgucKunt \& Levine, 1999). This is of particular interest in ascertaining the role of these financial intermediaries on economic growth and financial development in South Africa. Consequently, Demirguc-Kunt and Levine posit that the role of non-bank financial intermediaries differs across countries. For instance, in bank-based countries the role 
of non-bank financial intermediaries in undermined in favour of bank finance, while the role of non-bank financial institutions is more emphasized in market-based countries. Consequently, we expect greater development of nonbank financial institutions in market-based economies than in bank-based economies. However, regardless of economic orientation, the institutional investment industry is experiencing growth worldwide. This assertion has been supported by the results of an investigation into the role of institutional investors, financial efficiency and financial stability, which found that claims of institutional investors in Anglo-Saxon countries and Europe and Japan were $98 \%, 116 \%$ and $85 \%$, respectively (Davis, 2003). On the other hand, financial assets of institutional investors in OECD countries as a percentage of GDP rose from 110.2 percent in 1995 to 162.6 percent in 2005 (Gonnard, Kim, \& Ynesta, 2008), further showing the growing importance of these financial institutions in the modern financial system. Banking institutions have lost a considerable share in claims held in the financial system compared to institutional investors, and as such, extant evidence shows that institutional investors have been able to provide the functions of the financial system more effectively than their competitors (Davis, 2001).

According to Davis (2003), the growth of institutional funds has implications for the development of a robust financial sector if their asset allocations varied from those of individual investors. Davis (2003) found a twoway relationship which shows that despite the general notion that as the institutional investors grow, there is an emergence of new securities in the market or whether institutional investors emerge first then promote capital market development. However, this relationship has not been tested using econometric methodology. It may be argued that institutional investors are fast becoming more important in global financial markets, with their assets under management rapidly catching up with those of the banking industry (Committee on the Global Financial System, 2007). As such, Davis (2003) suggests institutional investors are a key financial innovation of recent years, causing a shift away from traditional bank intermediation, necessitating a re-evaluation of financial market structure and behaviour.

Finally, empirical evidence on the finance-growth nexus points to the chicken-egg situation. Some evidence suggests that financial development leads economic development, while others find it otherwise (Arestis \& Demetriades, 1997; Choong \& Chan, 2011; Demetriades \& Luintel, 1997; King \& Levine, 1993; R. Levine, 1997). These studies found that for developed market-based countries, financial development lead to economic development (supply-leading), and generally, in developing countries, economic development caused financial development (demand-following). Reviewed literature also suggests that institutional investors have a positive and significant relationship with economic development. Also it has been shown that institutional investors influence economic and financial development in other countries. However, despite a resilient financial system, there is a gap in the literature relating to the influence of these institutional investors on economic and financial development in South Africa.

\section{METHODOLOGY}

\subsection{Variables and Sources of Data}

This study uses quarterly data obtained from the South African Reserve Bank (SARB) online statistics spanning the first quarter in 1994 to the fourth quarter of 2009. Data points used in the study are the last trading day of each calendar quarter, i.e., data values obtained at the end of March, June, September and December in each year for those variables with greater frequency, and as per quarterly publications for those variables with less frequency. The key variables used in this study are described in Table 2.

Table 2: Description of Key Variables Used in This Study

\begin{tabular}{|l|l|}
\hline Percap & $\log$ [Real GDP per capita (2005) in South African rands] \\
\hline M2 & Log [ Broad Money Supply (M2)/GDP] \\
\hline MC & Log [Market Capitalization/GDP] \\
\hline BCP & Log [Domestic Credit provided by Banking Sector/GDP] \\
\hline IINV & $\begin{array}{l}\text { Log [Financial Assets of Institutional Investors/(Financial Assets of Institutional Investors + Market } \\
\text { Capitalization + Domestic Credit provided by Banking Sector)] }\end{array}$ \\
\hline GCF & Log [Gross Capital formation/GDP] \\
\hline
\end{tabular}




\subsubsection{Real GDP per Capita (Percap)}

The logarithm of real GDP per capita at 2005 constant prices is selected for this study to represent a measure of economic development in line with King and Levine (1993), and Choong and Chan (2011). The use of logarithm of real GDP per capita is in line with a notion that this mitigates variable's approximate exponential growth over time (Stock \& Watson, 2003). Log GDP per capita also helps avert multicollinearity problems between the model variables, as most variables are expressed as ratios of real GDP values. Because real GDP per capita figures are published on an annual basis by SARB and Statistics South Africa, we determine quarterly values through interpolation of the country's population data. Quarterly real GDP at 2005 constant prices that are sourced from SARB online statistics, and are then divided by the estimated population figures. Note, however, that Statistics South Africa publishes mid-year population estimates and provides population growth estimates which enable the approximation of the country's population with a quarterly frequency over the period under study. The real GDP per capita variable forms the basis of our theoretical model, discussed later, as it is used as a dependent variable in the model.

\subsubsection{Broad Money Supply to GDP Ratio (M2)}

Real broad money supply (M2) is used as the proxy for financial development (or financial deepness) and is calculated as a percentage of real GDP as suggested by Liu et al. (1997) and Dritsakis and Adamopoulos (2011). However, M2 may also be used to measure the extent of monetization rather than financial development, hence M2/GDP ratio is used to proxy both financial development and monetization. M2 values for this study are sourced from McGregor BFA Library database from 1994 to 2009 and then expressed as a percentage of the country's GDP.

\subsubsection{Stock Market Capitalization to GDP Ratio (MC)}

Several studies have used this ratio in the analysis of long-run relationships between stock market development and other economic and financial variables such as GDP growth, real GDP per capita and M2 to GDP ratios (Abu-Muhareb \& Al-Fayoumi, 2011; Choong \& Chan, 2011). Stock market capitalization ratio is widely regarded as a proxy measure of capital market development of a country. The larger the ratio the more developed the stock market. A major assumption in the use of this variable is that the market size is positively correlated with a firm's ability to raise capital and diversify risk across the economy (Levine \& Zervos, 1996). The stock market capitalization figures are obtained from the McGregor BFA Library database. Since stock market data is measured on a daily frequency, this study only uses end-of-quarter values for the analysis as described in 4.1 above. In other words, market capitalization values used are the closing values on the last trading day of each quarter in order to match the macroeconomic data published on a quarterly basis.

\subsubsection{Domestic Bank Credit to Private Sector to GDP Ratio (BCP)}

Domestic bank credit to private sector to GDP ratio measures the extent to which financial intermediaries funnel savings to investors in the economy (Harichandra \& Thangavelu, 2004). Specifically, this ratio is a proxy of the banking industry development and the larger the ratio the more developed the banking industry. Data for the domestic credit to private sector by banks are obtained from SARB Quarterly Bulletins and SARB online statistics. The data on domestic credit to the private sector is available on a quarterly frequency from 1994 to 2009 . The values of BCP are then divided by the country's GDP to obtain the BCP to GDP ratio.

\subsubsection{Institutional Investors' Asset Size (IINV)}

This variable has been used in the estimation of the impact of non-bank financial intermediaries on economic growth in Malaysia by Islam and Osman (2007). Harichandra and Thangavelu (2004) also suggested the use of the ratio of total assets of institutional investors to GDP to capture the role of institutional investors in economic development. Since, according to Harichandra and Thangavelu (2004) and Levine (1997), most financial assets of institutional investors consist of loans, stock and bonds, they should be normalized by dividing aggregate financial assets of institutional investors by the sum of total financial assets of institutional investors, domestic credit provided to private sector and stock market capitalization to cap multicollinearity problems in the regression model. 
In this paper, institutional investors include the Public Investment Corporation (PIC), mutual funds, pension funds, and short- and long-term insurance companies. Quarterly data is used for all these components of institutional investors. Data for all these institutional investors was obtained from the SARB online statistics from 1994 to 2009.

\subsubsection{Gross Fixed Capital Formation to GDP Ratio (GCF)}

The GCF variable represents other non-financial factors that affect economic growth and is suggested by Islam and Osman (2007). The inclusion of this variable in the model is to account for gross fixed capital formation in the economy, which, in theory, has a direct relationship with economic development. However, this variable is only included to capture a broad spectrum of factors that influence economic development in order to eliminate model misspecification. Data for GCF values are obtained from SARB online statistics and these figures are available with a quarterly frequency.

\section{THEORETICAL AND EMPIRICAL MODELS}

The underpinning theoretical model for this study is shown in Equation 1 below:

$G D P=f(B C P, I I N V, M 2, M C, G C F)$

where GDP is real GDP per capita, BCP is bank credit to private sector to real GDP ratio, IINV is institutional investment size ratio, M2 is money supply to GDP ratio, MC is stock market to GDP ratio, and GCF is Gross Capital Formation to GDP ratio. below:

Real GDP per capita is used as the dependent variable regressed against explanatory variables specified

$G D P_{t}=\alpha+\beta_{1} M C_{t}+\beta_{2} M 2_{t}+\beta_{3} B C P_{t}+\beta_{4} I I N V_{t}++\beta_{5} G C F_{t}+\mu_{i}$

where all variables are logarithms, $G D P_{t}$ is the real GDP per capita, $\alpha$ is the intercept, $M C_{t}$ is the stock market capitalization ratio, $M 2_{t}$ is the $\mathrm{M} 2$ money supply (financial development / monetization variable), $B C P_{t}$ is the domestic credit to private sector by banks ratio, $I I N V_{t}$ is the institutional investors asset ratio, $G C F_{t}$ is gross capital formation ratio, $\beta_{1,2,3 \ldots}$ are the respective coefficients.

The Augmented Dickey-Fuller tests (Dickey \& Fuller, 1979) and the Phillip-Perron tests (Phillips \& Perron, 1988) are used to test the null hypothesis that the series do not contain unit root. This is essential in the determination of whether the series are stationary or not and consequently in performing co-integration tests. If a series is stationary at levels then it is designated as I(0) (integrated of order zero) and if the series stationary at first differences then it is designated as I(1) (integrated of order 1) (Brooks, 2008; Johansen, 1991). The Johansen and Juselius co-integration tests are then used to ascertain the number of co-integration vectors. These are the Maximum Eigenvalue test, which tests the null hypothesis of $r$ co-integrating relations, and the Trace Test, which investigates the null hypothesis of $r$ co-integrating relations (Johansen \& Juselius, 1990).

The vector error correction (VEC) model is used to estimate the long-run relationship between the variables. The estimation procedure is based on Johansen (1991) co-integration tests, VEC model and subsequently the Granger Causality tests. VEC model provides both short-run and long-run relationships while dealing with time series properties in a robust manner. Arestis and Demetriades (1997) and Abu-Muhareb and Al-Fayoumi (2011) also used VECM as the estimation procedure in finding the relationship between macroeconomic variables and economic growth. The VEC model requires that co-integration be dictated between the series to confirm the existence of a long-run equilibrium between them. If no co-integration between the series exists, then the causal links may be derived from Granger causality tests while the short-run dynamics may be modeled through the vector autoregressive model (VAR). The VAR method helps if we are not confident in whether the variable is exogenous and hence treats each variable symmetrically (Enders, 2010). However, if co-integrating vectors exist in the series we have to use the VEC model. The VEC model qualifies to be used when the rank of $\Pi$ is reduced but greater than zero and may be expressed as: 
$\Delta y_{t}=\mu+\Pi y_{t-1}+\sum_{i=1}^{p-1} \Gamma_{i}^{*} \Delta y_{t-i}+\varepsilon_{t}$

where: $y_{t}$ denoted $m \times p$ vector of endogenous variables

$\mu$ is the $m \times 1$ vector of constants,

$\Pi=\sum_{\mathrm{j}=1}^{\mathrm{p}} \Gamma_{j}-1$ and $\Gamma_{i}^{*}=-\sum_{\mathrm{j}+1}^{\mathrm{p}}+\Gamma_{j}$

From the model, $\Gamma_{i}^{*}$ 's tells us about the short-run dynamics, and $\Pi$ tells us about the co-integrating relationships. We expect either one of the three sets of results regarding the rank of $\Pi$. Firstly, $\Pi$ may equal zero suggesting that no co-integration exists in the sequence at all. This occurs when all elements in the matrix $\Pi$ are zero. Thus the sequences are described as unit root processes and there is no co-integration (Brooks, 2008; Enders, 2010; Johansen, 1991). This means that the variables do not move together over time and the appropriate model to use is a VAR in the first differences involving no long-run elements. Secondly, the rank of $\Pi$ could be full (i.e. rank $=\mathrm{n}$ ), implying that the system is stationary and can be modeled by VAR in levels. Finally, the rank of $\Pi$ can be reduced (i.e. $0<$ rank $<$ n), implying that all variables are integrated of order $I(1)$ and the level based long-run component would be stationary. Thus, if there are $n-l$ co-integrating vectors the appropriate methodology will be the VEC model (Johansen, 1991).

The lead-lag relationship between two co-integrated variables ( $\mathrm{Y}$ and $\mathrm{X}$ ) may be expressed by the following equations:

$\Delta Y_{t}=\alpha_{1}+p_{1} e_{1}+\sum_{i=0}^{n} \beta_{i} \Delta Y_{t-i}+\sum_{i=0}^{n} \delta_{i} \Delta X_{t-i}+\sum_{i=0}^{n} \gamma_{i} \Delta Z_{t-i}$
$\Delta X_{t}=\alpha_{2}+p_{2} e_{i-1}+\sum_{i=0}^{n} \beta_{i} \Delta Y_{t-i}+\sum_{i=0}^{n} \delta_{i} \Delta X_{t-i}+\sum_{i=0}^{n} \gamma_{i} \Delta Z_{t-i}$

In Equation (5) and (6) $\mathrm{Y}$ will Granger cause $\mathrm{X}$ if lagged values of $\mathrm{Y}$ can be used to predict current and future values of $X$ better than just using lagged values of $X$. In using the VEC model the co-integrating rank will show the number of co-integrating vectors. The speed of adjustment coefficients represented by $\mathrm{p}_{1}$ and $\mathrm{p}_{2}$ articulates the rate of adjustment towards equilibrium in the equation. These coefficients should be statistically significantly different from zero to explain that there is a correction of short-run deviations in the long run (Brooks, 2008; Enders, 2010; Johansen, 1991). Furthermore, the speed of adjustment coefficients should not be too large for the model to be accurate and reliable. A negative and significant coefficient of the error correction model $\left(e_{i-1}\right)$ shows that any short-run fluctuations between the exogenous variables and the endogenous variables will give rise to stable longrun relationship between the variables. The study also uses the Granger causality tests and impulse response functions to establish the relationship between institutional investors and other variables used in the study (Granger, 1969; Liu et al., 1997; Sims, 1980).

\section{EMPIRICAL RESULTS AND DISCUSSION}

The test of the time series properties of all the variables through the use of confirmatory data analysis, which entail joint unit root and stationary tests, is performed using ADF and PP (Enders, 2010; Islam \& Osman, 2007). If the entire series are integrated of order $I(1)$, we further test for co-integration and then employ the VEC model and the Granger causality tests. Post-estimation tests are conducted to test the stability of the VEC model. The ADF and PP techniques are employed assuming a constant and no deterministic trend to test the null hypothesis that the series contains a unit root $\left[\mathrm{H}_{0}: y_{\mathrm{t}} \sim I(1)\right]$ against the alternative that the series does not contain a unit root $\left[\mathrm{H}_{1}: y_{\mathrm{t}} \sim I(0)\right]$.

The ADF and PP reveal that the entire series contains a unit root; hence we fail to reject the null hypothesis that the series contains a unit root. However, we strongly reject the null that the series contains a unit root after first differencing suggesting the series should be first differenced and are integrated of order I(1). Summary unit root and stationary test results using ADF and PP are shown in Tables 3 and 4 respectively. 
Table 3: ADF Unit Roots Tests Results

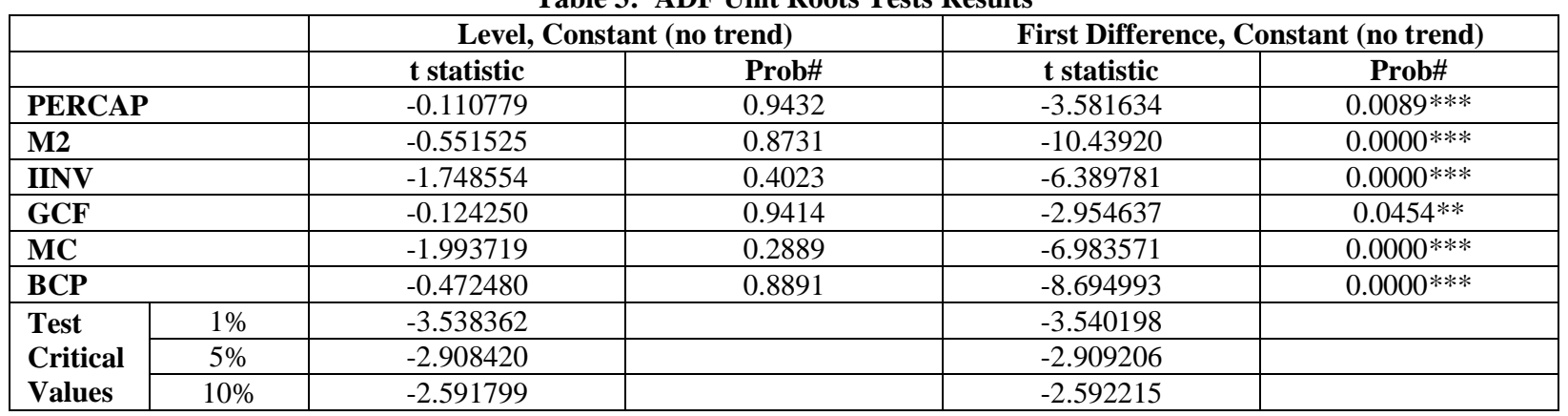

\#MacKinnon (1996) one-sided p-values. *** Statistically significant at 1 percent.

Table 4: PP Unit Roots Tests

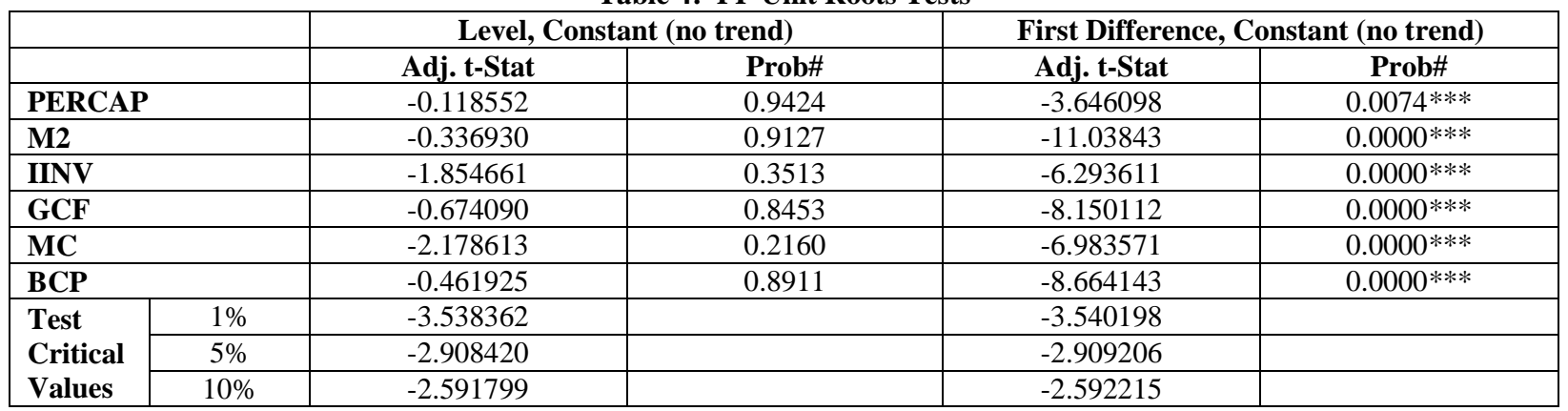

\# MacKinnon (1996) one-sided p-values. ${ }^{* * *}$ Statistically significant at 1 percent.

To conduct robustness tests we first determine the lag length for the series based on the Schwarz Bayes Information Criterion (SBIC). We obtain a lag length of two, and hence we use two lags for the analysis. The number of co-integrating relations (equations) is determined using both the trace test and the maximum eigenvalues. Assuming linear data trend, with an intercept and no trend, we obtain a maximum of two co-integrating equations under the trace statistic and one co-integrating equation using Maximum-Eigenvalues at 5 percent significance level. This suggests that the rank of $\Pi$ is neither zero nor full, hence the series could be analyzed using the VEC model. A summary of the number of co-integrating relations at 5 percent significance level is shown in Table 5 below.

Table 5: Number of Co-Integrating Relations by Model

\begin{tabular}{|l|c|c|c|c|c|}
\hline & Case 1 & Case 2 & Case 3 & Case 4 & Case 5 \\
\hline Data Trend: & None & None & Linear & Linear & Quadratic \\
\hline Test Type & No Intercept & Intercept & Intercept & Intercept & Intercept \\
\hline & No Trend & No Trend & No Trend & Trend & Trend \\
\hline Trace & 3 & 3 & 2 & 2 & 2 \\
\hline Max-Eig & 3 & 3 & 1 & 1 & 1 \\
\hline
\end{tabular}

*Critical values based on MacKinnon-Haug-Michelis (1999)

The co-integrating equation chosen is based on case 3 of the VEC model as shown in Table 5 above. With the exception of $\mathrm{M} 2$, the resultant co-integrating equation shows that the coefficient signs are positive and significant, which are consistent with financial theory. The Johansen (1991) co-integrating equation under the VEC model and after normalizing for the PERCAP variable is expressed in equation 7 (with standard errors in parenthesis).

$$
\begin{array}{r}
P E R C A P=3.96+0.106 M C+0.470 I I N V+5.545 G C F+1.006 B C P-1.608 M 2 \\
(0.2393)^{*}(0.0199)^{*}(0.1817)^{*}(0.6888)^{*}
\end{array}
$$

The positive and significant coefficients signs meet a priori expectations in terms of the direction of the variable's contribution to economic development as described in Equation 2. With regard to institutional investors, a 
one unit change in institutional investors' assets would lead to a 0.47 change in the size of economic development (percap). The relationship is statistically significant at 5 percent. The signs of stock market development (MC) and banking sector development (BCP) confirm the finance-growth nexus. This result is consistent with the findings of Islam and Osman (2007). The relationship between institutional investors and economic development is more pronounced than that of stock market development. A unit change in stock market development leads to 0.10 change in economic development. However, a unit change in banking sector development results in a unit change in economic development. This shows that the banking sector development influences economic development in greater magnitude than institutional investors and the stock market. The VEC model error correction terms are shown in Table 6 below (with standard errors in parenthesis).

Table 6: Error Correction Terms

\begin{tabular}{|l|c|c|c|c|c|c|}
\hline Error Correction: & D(PERCAP) & D(M2) & D(MC) & D(IINV) & D(GCF) & D(BCP) \\
\hline CointEq1 & -0.033443 & -0.284301 & $-5.855485^{*}$ & $0.373260^{*}$ & $0.172453^{*}$ & $0.046158^{*}$ \\
\hline & $(0.02688)$ & $(0.17378)$ & $(1.81243)$ & $(0.12069)$ & $(0.03357)$ & $(0.22901)$ \\
\hline
\end{tabular}

significant at 5 percent

Only economic development (percap), broad money supply (M2) and stock market development have negative coefficients. However percap and M2 are statistically insignificant. Of interest is the positive coefficient of the institutional investors' variable, which suggests that 37 percent of short-run disturbances correct downwards to give rise to long-run equilibrium. More than 70 percent of the disturbances corrected within two quarters. Furthermore, the insignificant coefficient of percap means that the variable does not adjust to disturbances.

The Granger causality from the VEC model results fail to provide evidence that institutional investors influence economic development, financial development and gross capital formation, despite a long-run cointegrating relationship found in Equation 7 above. This means that institutional investors cannot be used to predict changes in economic development, financial development and gross capital formation. As such, the three null hypotheses that institutional investors influence (i) economic development, (ii) financial development, and (iii) gross capital formation, are rejected. However, the one lagged percap shows a unidirectional causality to stock market development ( $\mathrm{t}$-statistic $=3.4413$ ) and institutional investors ( $\mathrm{t}$-statistic $=-3.3402)$. Moreover, the results show that a relationship exists between the banking sector development and institutional investors, where the one and two lagged banking sector development proxy (BCP) have unidirectional causality with t-statistic of 2.6433 and 2.2301, respectively. This result contradicts findings by Harichandra and Thangavelu (2004) that no relationship exists between the BCP and institutional investors.

The Granger causality tests reveal that economic development and banking sector development can be used to predict changes in institutional investors' assets, however, without any reverse feedback. These results show that economic development can be used to predict changes in institutional investors' assets in line with the Patrick (1966) 'demand-following' proposition. The fact that institutional investors are 'demand-following' means that they compete with banks for savings arising from economic development. This is in line with the Davis (2003) assertion that the development of institutional investors leads to financial disintermediation. The finance-growth nexus is confirmed by the relationship between the stock market and economic development. In this relationship, results show that economic development can be used to predict changes in the stock market development.

The impulse response functions show the response of one variable to another variable (for example, response of bank credit to private sector to a unit shock in institutional investors' assets) shown in Figure 1. These further confirm the relationship between institutional investors and other macroeconomic variables. 
Response to Cholesky One S.D. Innovations
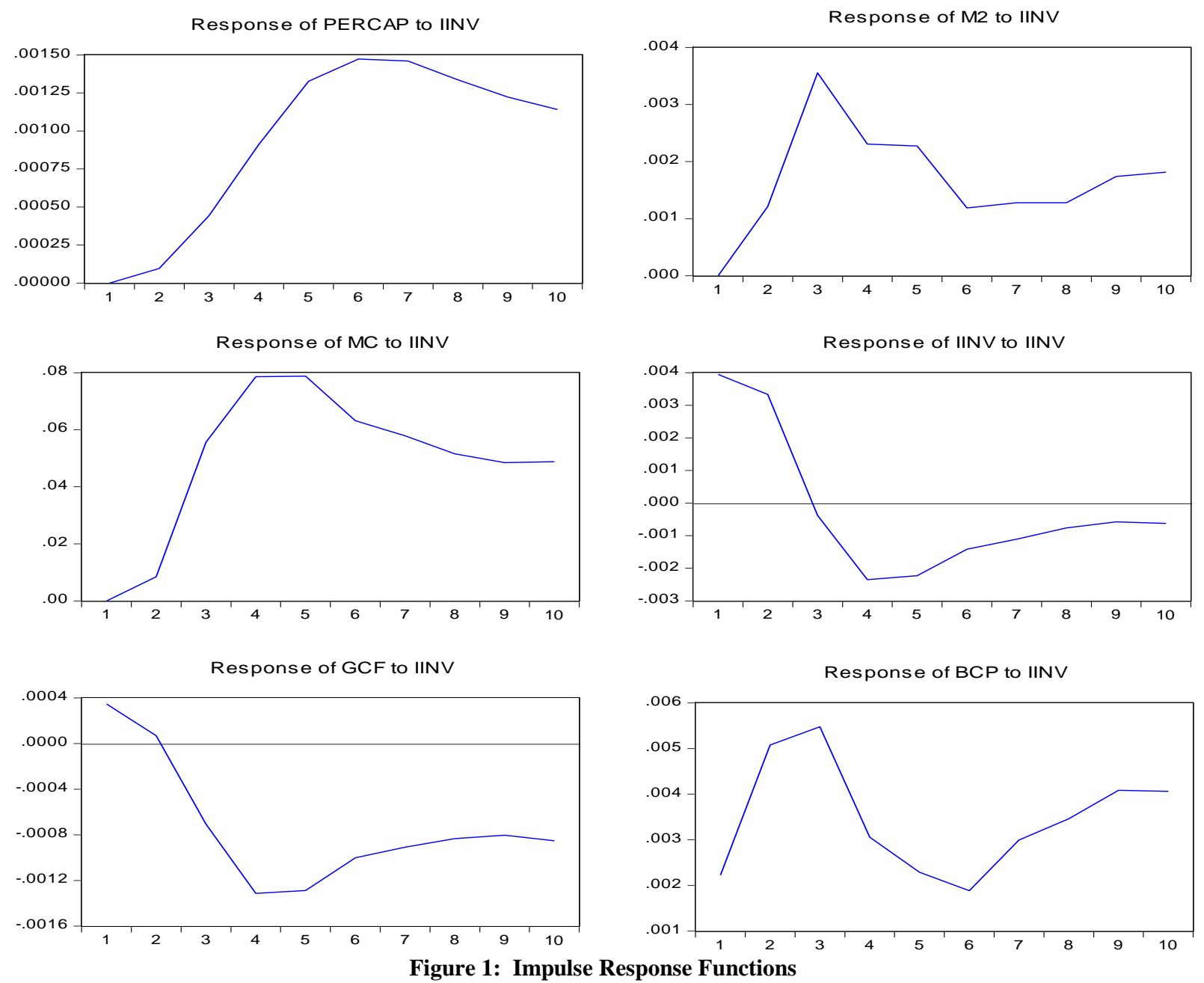

\section{CONCLUSIONS}

This study sought to establish the influence of institutional investors on the finance-growth nexus in South Africa using the Johansen (1991) co-integration procedure and ultimately the VEC model and the Granger causality tests. The results show that a long-run co-integration relationship exists between the economic development, financial development and institutional investors. The results of the study further reveal that despite the non-bank financial intermediaries being ranked higher than the banking sector, the influence of the former on economic development is not evident. Instead the institutional investors' growth is influenced by economic development and banking sector development. The inference of the above findings shows that institutional investors are dependent on macroeconomic factors such as economic development for growth. It can also be concluded that a positive association between economic development and financial development exists, as found by the Johansen (1991) cointegration tests. However, lack of association between institutional investors and gross capital is a cause for concern. Overall, the study shows that institutional investors do not drive economic development, financial development and gross fixed capital formation. Accordingly, we conclude that institutional investors in South Africa are heavily dependent on economic development and banking sector development for growth. Of interest, we find that the relationship between economic development and the financial sector is greatly driven by banking sector development, followed by institutional investors and then the stock market. Thus, emerging market economies should focus on economic development initiatives and grow their banking sector in order to develop strong nonbank financial institutions. 


\section{AUTHOR INFORMATION}

Dr. Mabutho Sibanda is a blended academic with six years investment banking experience and eight years university lecturing experience. Mabutho holds an MSc in Finance and Investment from the National University of Science and Technology, Zimbabwe, and received a $\mathrm{PhD}$ in Finance from the University of KwaZulu-Natal, South Africa. He is a Member of the Investments Analysts Society South Africa and an Associate Member of the Institute of Risk Management South Africa. Mabutho is currently Finance lecturer at the University of KwaZulu-Natal in South Africa. E-mail: sibandam@ukzn.ac.za (Corresponding author)

Professor Merle Holden is Emeritus Professor in the School of Accounting, Economics and Finance at the University of KwaZulu-Natal, Durban. After graduating from the University of Natal with an Honours degree, she completed her graduate study in the US and holds a Ph.D. in Economics from Duke University. She was Associate Professor of Economics at George Mason University in Virginia, US, before returning to South Africa in 1982 to the University of Natal. She served as Head of the School of Economics and Management and Dean of the Faculty at the University of Natal. She has been a part time member of the Competition Tribunal of South Africa since 1999. E-mail: merleholden@gmail.com

\section{REFERENCES}

1. Abu-Muhareb, E. F., \& Al-Fayoumi, N. A. (2011). Stock markets, banks and economic growth: Empirical evidence from Jordan. Working paper. Amman: Department of finance, Faculty of Business, University of Jordan.

2. Allen, F., Qian, J., \& Qian, M. (2005). Law, finance, and economic growth in China. Journal of Financial Economics, 77(1), 57-116.

3. Allen, F., \& Santomero, M. (1997). The theory of financial intermediation. Journal of Banking and Finance, 21, 1461-1485.

4. Arestis, P., \& Demetriades, P. O. (1997). Financial development and economic growth: Assessing the evidence. Economic Journal, 107, 783-799.

5. Aziakpono, M. (2003). Financial Intermediation and economic growth in economic integration: The case of SACU. Paper presented at the ESSA Conference, Sommerset West., Lord Charles Hotel, Somerset.

6. Bisignano, J. (1998). Towards an understanding of changing structure of financial intermediation -An evolutionary theory of institutional survival. Paper presented at the SUERF - The European Money and Finance Forum.

7. Brooks, C. (2008). Introductory econometrics for finance (2nd ed.). United Kingdom: Cambridge.

8. Choong, C., \& Chan, S. (2011). Financial development and economic growth: A review. African Journal of Business Management, 5(6), 2017-2027.

9. Choong, C., Yusop, Z., Law, S. H., \& Sen, V. L. K. (2005). Financial development and economic growth in Malaysia: The stock market Perspective. Investment Management and Financial Innovations, 5, 105-115.

10. Committee on the Global Financial System. (2007). Institutional investors, global savings and asset allocation. CGFS Papers: Bank of International Settlements.

11. Davis, E. P. (2001). Institutional investors, financial market efficiency and financial stability. National Institute of Economic and Social Research.

12. Davis, E. P. (2003). Financial development, institutional investors and economic performance. Salford University.

13. Demetriades, P. O., \& Luintel, K. B. (1997). Financial Development, economic growth and bank sector controls: Evidence from China. Economic Journal, 106, 359-374.

14. Dermirguc-Kunt, A., \& Levine, R. (1999). Bank-based and market-based financial systems-cross-country comparisons. Policy Research Working Paper The World Bank. Washington.

15. Dickey, D. A., \& Fuller, W. A. (1979). Distribution of the estimators for autoregressive time series with a unit root. Journal of the American Statistical Association, 74, 427-431.

16. Dritsakis, N., \& Adamopoulos, A. (2011). Financial development and economic growth in Greece: An empirical investigation with granger causality analysis. Working Paper. Department of Applied Informatics. University of Macedonia. Greece. 
17. Enders, W. (2010). Applied econometric time series. Hoboken: John Wiley \& Sons.

18. Gonnard, E., Kim, E. J., \& Ynesta, I. (2008). Recent trends in institutional investors statistics. Financial Markers Trends, Organization for Economic Co-operation and Development, 2(95).

19. Granger, C. W. J. (1969). Investigating causal relations by econometric models and cross-spectral methods. Econometrica, 37(3), 424-438.

20. Harichandra, K., \& Thangavelu, S. M. (2004). Institutional Investors, financial sector development and economic growth in OECD countries. Working Paper Department of Economics. National University of Singapore,.

21. International Monetary Fund (IMF). (2011). South Africa Financial Sector Profile. Washington.

22. Islam, M. A., \& Osman, J. (2007). Non-bank financial intermediaries and economic growth in Malaysia: An application of the ARDL bounds testing approach to cointegration. Journal Ekonomi \& Studi Pemangunan, 8(2), 130-141.

23. Johansen, S. (1991). Estimation and hypothesis testing of cointegrating vectors in Gaussian Vector Autoregessive Models. Econometrica, 59, 1551-1580.

24. Johansen, S., \& Juselius, K. (1990). Maximum Likelihood estimation and inference on cointegrated with applications to the demand for money. Oxford Bulletin of Economics and Statistics, 52, 169-210.

25. King, R., \& Levine, R. (1993). Finance and growth: Schumpeter might be right. Policy Research. Working Paper. The World Bank.

26. Levine, R. (1997). Financial development and economic growth: Views and agenda. Journal of Economic Literature, 35(2), 688-726.

27. Levine, R., \& Zervos, S. (1998). Stock markets, banks and economic growth. Policy Research Working Paper, 1690, 1-32.

28. Levine, R., \& Zervos, S. (1996). Stock market development and long run growth. The World Bank Economic Review, 10(2), 323-339.

29. Liu, X., Song, H., \& Romilly, P. (1997). An empirical investigation of the causal relationship between openness and economic growth in China. Applied Economics Journal, 29, 1679-1686.

30. Patrick, H. T. (1966). Financial development and economic growth in underdeveloped countries. Journal of Economic Development and Cultural Change, 14, 174-189.

31. Phillips, P., \& Perron, P. (1988). Testing for a unit root in time series regression. Biometrica, 75, 335-346.

32. Sims, C. A. (1980). Macroeconomics and reality. Econometrica, 48(1), 1-48.

33. Solow, R. M. (1956). A contribution to the theory of economic growth. Quarterly Journal of Economic Growth, 70(1), 65-94.

34. Stock, J. H., \& Watson, M. W. (2003). Introduction to Econometrics. (International Edition ed.): Addison Wesley.

35. World Economic Forum. (2012). The Financial Development Report 2012. Retrieved 31 May 2013, from http://www3.weforum.org/docs/FDR/2012/50_South_Africa_FDR12.pdf 